\title{
Reservoir Petrophysical Modeling and Risk Analysis in Reserve Estimation; A Case Study from Qasr Field, North Western Desert, Egypt
}

\author{
Farouk I. Metwalli ${ }^{1}$, El- Arabi H. Shendi ${ }^{2}$, Mohamed S. Fagelnour ${ }^{3}$ \\ ${ }^{\prime}$. Geology Department, Faculty of Science, Helwan University, Cairo, Egypt. \\ 2. Geology Department, Faculty of Science, Suez Canal University, Ismailia, Egypt. \\ ${ }^{3}$. Khalda Petroleum Company, Cairo, Egypt.
}

\begin{abstract}
The Full assessment of an oil and/or gas field is a matter of a complex and interacting processes, including geological, engineering, and economical aspects. This work has been applied on Qasr oil field, which is located in the North Western Desert of Egypt. The Reservoirs are sandstones of Khatatba and Alam El Bueib Formations. Alam El Bueib Formation is divided into six units and the oil bearing unit is AEB-3. It is divided into seven sub-units. This research work focuses on the geological process, coupled with volumetrics and some statistical analysis, to determine the possibility to fully develop Qasr oil field in the northern Western Desert of Egypt. The first step will be building the geological model, parallel with the Petrophysical analyses of well logs and other well data, then volumetric calculations using input data to obtain field reserves. The selection of the most important and uncertain parameters and the definition of associated probabilities can help at the end in accurate estimation of reserves. The Data used included electric well logs from ten wells, core analysis data from one well, and a structural geological model in order to make the stochastic petrophysical model. This work showed the role of the integration between petrophysical analysis, modeling, volumetric calculation and risk analysis in order to make accurate reserve estimations. Results confirmed that Alam El Bueib sandstone reservoirs having good petrophysical properties and their stochastic distribution were assured by a number of producing wells.
\end{abstract}

Keywords: Petrophysical Modeling, Risk Analysis, Reserve Estimation, Qasr Field, Egypt.

\section{Introduction}

The Estimation of reserves, coupled with geological modeling and risk analysis, was done by many workers. The construction of geological model, and the Statistical treatment of the results, with uncertainty and risk, can be used to improve the quality of the results [1]. The 3-D Static Modeling of the KN field, offshore Niger Delta, has provided a better understanding of the spatial distribution of the discrete and continuous properties in the field. The study has also created a geological model for $\mathrm{KN}$ field that can be updated as new data are acquired for field development. The model could be transferred to the reservoir engineer for proper characterization during simulation [2]. The quality of petrophysical analysis leads to a better reserve calculation [3-5]. The applications of electric well log analysis are important in determining petrophysical parameters in different areas [6-10].The Western Desert province in Egypt is still one of the promising oil and gas producing areas [11-16].Qasr field is located in the North Western Desert of Egypt, between Latitudes: 30³9'24.296"N \& $30^{\circ} 34^{\prime} 56.70^{\prime \prime N}$ and Longitudes: $26^{\circ} 38^{\prime} 04.9796 " \mathrm{E} \& 26^{\circ} 45^{\prime} 56.64^{\prime \prime} \mathrm{E}$, (Figure.1). Geologically, it belongs to the eastern Shushan Basin which ranges in age from Paleozoic to Quaternary [17-19]. (Figure.2). Source rocks for this province are regarded as mature oil and gas prone shales of the Lower to Middle Jurassic Khatatba Formation, and some oil prone shales in the Alam El Bueib shales of the Lower Cretaceous age. The reservoirs are sandstones of Khatatba and Alam El Bueib Formations. Alam El Bueib Formation is divided into six units and the oil bearing unit is AEB-3. It is divided into seven sub-units (A, B, C, D, E, F and G).

\section{Data and Methods}

Data from 10 wells at Qasr field were used. Data included with their mud logs and electric logs including: Gamma Ray ;( either computed or spectral), Resistivity ;( deep, medium or shallow), Neutron, Density and sonic logs. The electric logs are environmentally corrected during processing. Porosity and Water Saturation Cutoffs were obtained from core data. The structural geological model was constructed from a using previously interpreted depth maps and faults. Petrophysical analysis was performed using Interactive Petrophysics (IP) software, while well correlation and modeling were carried out using Petrel software. 


\section{Petrophysical analysis of reservoir zones}

Four main Petrophysical parameters are important in defining any reservoir, which are: effective porosity (PHIE), water saturation (SW), net reservoir, here in sand (NSD) and net pay thickness (NEP) [2021].The Re-evaluation of some wells in the study area helped in determining new promising zones and updating the Petrophysical maps used in field development. The Interactive Petrophysics (IP) software was used in petrophysical analysis with the following scheme:

1.1. Reservoir zonation: Reservoir zones' depths measured in feet (ft.) and obtained from well correlation.

\subsection{Temperature gradient calculation}

The geothermal gradient $(\mathrm{G})$ is important in determining formation temperature $\left(\mathrm{T}_{F M}\right)$. Geothermal gradient was calculated from the following equation:

$$
\mathrm{G}=\frac{\left(\mathrm{BHT}-\mathrm{T}_{\mathrm{s}}\right)}{\mathrm{D}_{\mathrm{T}}}
$$

Where: BHT: the bottom hole temperature, $\mathrm{T}_{\mathrm{S}}$ : the surface temperature,

$\mathrm{D}_{\mathrm{T}}$ : the total depth.

1.3. Clay volume analysis: Clay volume determination is important to differentiate between reservoir and nonreservoir zones. The tool used here is Gamma Ray and Clay Volume ( $\left.\mathrm{V}_{\mathrm{CLAY}}\right)$ cutoff equals $(0.35)$ was used here for sandstone reservoir.

\subsection{Formation water resistivity $\left(R_{W}\right)$ :}

Several methods have been used to calculate formation water resistivity; among them $\mathrm{R}_{\mathrm{W}}$ from SP, and applying Archie equation in a fully water saturated reservoir, since $\mathrm{SW}=1$, and $\mathbf{R}_{\mathrm{W}}=\mathbf{R}_{\mathrm{T}}$, where $\mathrm{R}_{\mathrm{T}}$ is the true resistivity measured by deep resistivity measurements (LLD for example). In this work we use the formation water resistivity measured from core analysis where $\mathrm{R}_{\mathrm{W}}=0.019 \mathrm{ohm} @$ Temperature $220 \mathrm{deg}$. F.

\subsection{Porosity determination:}

The total porosity is the average of the two measurements obtained from Density $\left(\emptyset_{\mathrm{D}}\right)$ and Neutron $\left(\emptyset_{\mathrm{N}}\right)$ :

$$
\emptyset_{\mathrm{T}}=\left(\emptyset_{\mathrm{D}}+\boldsymbol{\emptyset}_{\mathrm{N}}\right) / \mathbf{2}
$$

The effective porosity is the actual porosity needed in determining water saturation and reserve estimation. The effective porosity is obtained from total porosity after eliminating the effect of shale: $\boldsymbol{\emptyset}_{\mathrm{E}}=\boldsymbol{\emptyset}_{\mathrm{T}} \times\left(\mathbf{1}-\mathbf{V}_{\mathrm{CLAY}}\right)$. Porosity cutoff used here equals $8 \%$.

\subsection{Water saturation determination:}

The Indonesian method for calculating water saturation in shaly formations is applied [22]. Water saturation cutoff used here equals $50 \%$. A multi- mineral analysis default is applied to interpret three reservoir lithologies which are Sand, Lime and Dolomite from given logs.

\subsection{Bad-hole correction:}

The analysis of holes of severe damage is eliminated due to inaccurate measurements. Since all studied wells are drilled by 12.25 inch bit, the hole diameter greater than 13.25 inch, is regarded as bad hole. Bad holes appear mostly in highly argillaceous zones

\section{Petro physical Analysis Results}

Ten wells in the study area were analyzed carefully using available electric logs, these wells are (Qasr3,-7,-10,-31, -36, -41, -42,-45,-48, and Qasr-49). The Petrophysical analysis of well Qasr-3 showed that the well is dry due to bad reservoir quality and facies change. The Petrophysical analysis of well Qasr-31, (Figure.3) showed good results in unit AEB-3D, with a (D2) net pay thickness of $23 \mathrm{ft}$., average porosity $13 \%$ and water saturation $7 \%$. The (D4) showed a net pay of $44 \mathrm{ft}$, , average porosity $12 \%$ and water saturation $12 \%$. The AEB$3 \mathrm{E}$ unit showed a net pay thickness of $4 \mathrm{ft}$., average porosity $11 \%$ and water saturation $41 \%$. The Petrophysical analysis of well Qasr-36, (Figure.4) showed good results in unit AEB-3D, with the (D2) net pay thickness 21 $\mathrm{ft}$., average porosity $10 \%$ and water saturation $9 \%$. The (D4) showed a net pay thickness of $16 \mathrm{ft}$., average porosity $11 \%$ and water saturation 47\%. The Petrophysical analysis of well Qasr-41, (Figure.5) showed scattered reservoir in unit AEB-3C, with a total net pay thickness of $10 \mathrm{ft}$., average porosity $9 \%$ and water saturation 37\%. The top of unit AEB-3D showed poor net pay of only $3 \mathrm{ft}$., with average porosity $10 \%$ and water saturation $31 \%$. While, the (D2) showed a continuous net pay thickness of $49 \mathrm{ft}$., with average porosity 12 $\%$ and water saturation 17\%.The Petrophysical analysis of well Qasr-42, (Figure.6) showed continuous reservoir in unit AEB-3D, with the (D4) net pay thickness of $25 \mathrm{ft}$., average porosity $13 \%$ and water saturation $17 \%$. The (D2) is a non- reservoir due to facies change and the dominance of shale lithology. The Petrophysical analysis of well Qasr-45, (Figure.7) showed a net pay thickness of $7.5 \mathrm{ft}$., with average porosity $12 \%$ and water saturation $37 \%$ in AEB-3D unit (D4). The AEB-3E sandstone reservoir is wet in all wells since it is located below the known oil water contact (OWC $=11040 \mathrm{ft}$. subsea depth). Although most of the pay is found in unit AEB-3D, (D2 \& D4) in all wells, some wells have noticeable pay in units AEB-1,-2,-3a, and AEB-3C, and can 
be regarded as a secondary target. The Petrophysical analysis of well Qasr-7 showed a continuous reservoir in Unit AEB-3C, with net pay $25 \mathrm{ft}$., average porosity $11 \%$ and water saturation $21 \%$. The AEB-3D sandstone reservoir showed a continuous net pay thickness $28 \mathrm{ft}$., average porosity $12 \%$ and water saturation $12 \%$. The Petrophysical analysis of well Qasr-10 showed multiple pay. A scattered reservoir with marginal pay is shown in units AEB-1,-2 and -3A. AEB-1 showed net pay thickness $8 \mathrm{ft}$., average porosity $12 \%$ and water saturation $41 \%$. The AEB-2 sandstone reservoir showed net pay thickness $8 \mathrm{ft}$., average porosity $14 \%$ and water saturation $30 \%$. The AEB-3A sandstone reservoir showed $7 \mathrm{ft}$.net pay thickness, average porosity $12 \%$ and water saturation 44\%.Units AEB-3C and -3D of in well Qasr-10 showed a scattered reservoir with marginal pay. AEB-3C showed a net pay thickness of $22 \mathrm{ft}$., average porosity $10 \%$ and water saturation $29 \%$. The AEB-3D sandstone reservoir showed a net pay thickness of $18 \mathrm{ft}$., average porosity $12 \%$ and water saturation $34 \%$. Well Qasr-48 showed a marginal pay in units AEB-3A,-3C and -3D, while AEB-3A unit showed 14 ft.net pay thickness, average porosity $10 \%$ and water saturation 43\%.AEB-3C showed a net pay thickness of $20 \mathrm{ft}$., average porosity $11 \%$ and water saturation $38 \%$. The AEB-3D sandstone reservoir showed a net pay thickness of $9 \mathrm{ft}$., average porosity $9 \%$ and water saturation 41\%. The AEB-3D sandstone reservoir in well Qasr-49 showed a net pay thickness of $6 \mathrm{ft}$., average porosity $11 \%$ and water saturation $39 \%$.

\section{Petro physical Modeling}

In this procedure; the calculated Petrophysical parameters of the reservoir (such as porosity, water saturation and net to gross pay thickness) are distributed spatially in the 3D grid. This is important for accurate estimation of the hydrocarbon reserve, and determination of an oil field economics. Two major sub-processes are necessary for generating a Petrophysical model:

3.1. Scale up well log: Where the Petrophysical parameter is distributed within each cell according to well log values (Figure.8) the following parameters were used:

3.1.1. Arithmetic means: The average value of property in each cell is calculated.

3.1.2. As lines: If a midpoint of a line between two sample points is inside a cell, the point outside the cell will be used in the calculation.

3.1.3. Neighbor cell: all penetrated cells will be used in calculation, and those which are not penetrated cells will be averaged.

3.2. Sequential Gaussian Simulation: Because data are not dense enough to run a deterministic method, the Sequential Gaussian Simulation algorithm will be used. It is a stochastic method and the technique is pixel based. This algorithm is faster to run and faster to update. Petrophysical parameters are distributed through the facies of each zone, and Four Petrophysical models are generated, namely, porosity, permeability, water saturation, and net to gross pay thickness [23].

3.2. 1. Porosity model: This model is generated by distributing the effective porosity (PHIE) into the $3 \mathrm{D}$ grid cells. The effective porosity is calculated from neutron and density logs in each well and it represents the actual storage capacity of the rock. The porosity of sandstone reservoirs of Alam El Bueib Formation averages 14-16 $\%$ and the lower units (AEB-3D, AEB-3E) shows better porosity values than upper ones (Figure.9).

3.2. 2. Water Saturation model: This model is generated by distributing the water saturation (SW) into the $3 D$ grid cells. It is a good indication for hydrocarbon saturation, which is the remaining fraction in pores. SW having values ranging from $7 \%$ to $47 \%$ in the sandstone reservoirs of all zones (Figure.10).

3.2. 3. Net to Gross Pay Thickness Model: This model is generated by distributing the net to gross pay thickness (N/G) into the 3D grid cells. It is the ratio of pay thickness (PayFlag) to reservoir thickness (ResFlag).

\section{N/G=PayFlag/ResFlag}

Most sandstone reservoirs having N/G values up to 90\%, especially for the lower AEB-3D and AEB-3E zones. It is an important parameter in reserve calculations since it represents the thickness of hydrocarbon in a reservoir (Figure.11).

\section{Reserve Estimation}

The commercial value of a field can be inferred from its hydrocarbon reserves, either oil or gas, or both. The Alam El Bueib sandstones in Qasr field are oil bearing reservoirs. Using available reservoir data, a more sophisticated formula may be applied [24]:

$$
\text { Recoverable oil }(\mathrm{bbl})=\frac{7758 V \phi\left(1-S_{\mathrm{w}}\right) R}{\mathrm{FVF}}
$$

Where: $\mathrm{V}=$ the volume (area $\times$ thickness), $7758=$ conversion factor from acre-feet to barrels, $\varnothing=$ average effective porosity, $\mathrm{S}_{\mathrm{W}}=$ average water saturation, $\mathrm{R}=$ estimated recovery factor, $\mathrm{FVF}=$ formation volume factor. Porosity and water saturation are calculated from well logs and calibrated from core data. Log and test data establish the oil water contact and hence; the thickness of the hydrocarbon column [25]. It is hard to estimate the 
recovery factor, but average values can be applied. The FVF converts a stock tank barrel of oil to its volume at reservoir temperatures and pressures. The FVF depends on the gas: oil ratio (GOR) and oil density (API gravity). The FVF ranges from 1.08 for low GORs and heavy crudes to values of more than 2.0 for volatile oils and high GORs. The volume is the product of multiplying oil thickness by reserve area inside the oil water contact on the map which equals 13525 acres (Figure.12). The oil water contact is set at depth of $11040 \mathrm{ft}$. SSTVD. The thickness of oil column itself is variable; in addition, porosity and water saturation having values that change from one location to another. The importance of modeling, in line with high processing computers and advanced software, is to calculate reserves most accurately and rapidly. Using FVF that equals 1.3 and recovery factor that equals 0.4 ; the estimated reserves for zones from unit AEB-1 to unit AEB-D4 sandstone reservoirs are displayed in Table.1. The Bulk volume is the rock volume, which is the product of multiplying the reserve area by reservoir thickness, while the Net volume is the product of multiplying the reserve area by net to gross pay thickness. The abbreviation (HCPV) refers to hydrocarbons in pore volume by barrel, while (STOIIP) refers to stock tank oil in place. The (HCPV) is the product of Pore volume and Porosity, and (STOIIP) is the product of (HCPV) and hydrocarbon saturation $\left(1-\mathrm{S}_{\mathrm{h}}\right)$. The recoverable oil is obtained after multiplying by the recovery factor, and is representative for the reservoir storage and commercial productivity. The AEB-3D zone, including 3D, D2 and D4, showed the highest recoverable oil reserve, 21 million stock tank barrels, while the least, 4 million stock tank barrels, were found in AEB-1 and AEB-2. Although other zones have noticeable reserves, but the continuity of a reservoir is hard to detect, since facies are changing variably in zones AEB-3C, -2, and AEB-1. Because the reservoir is thick and continuous to some extent, the AEB-3D sandstones are regarded as the primary targets in Qasr field, while other thin and marginal oil bearing zones are secondary targets and can add more value to the oil reserve and production on the long run.

\section{Success And Play Chance Maps}

Play chance mapping enables us to complete petroleum the system evaluation of hydrocarbon potential and the associated risks for a play within a field. The results can be used in making decisions when prioritizing opportunities from different areas [26]. Play chance maps are created to define the petroleum system elements, such as trap, reservoir, charge and seal, using geologically based transforms [27]. The prospect assessment ties volumetric calculations and allows for a betterchance of success, together in one integrated process. For a chance of success map (COS), if the trap charge is set to be 1 , seal 0.8 and preservation 0.9 ; then the resrvoir rock presence isgiven by net sand map and quality by net pay map. The value of (COS) ranges between 0 and 1 for the overall play. Two zones were selected for this study; which are namely;D2 and D4 sandstone reservoirs. The AEB-3D (D2) (Figure.13) play showed COS value up to 0.6 with its maximum in E, SE and $\mathrm{W}$ directions of Qasr field. On the other hand, The AEB-3D (D4) (Figure.14) play showed COS value up to 0.55 with its maximum in SE and NW directions.

\section{Field Assessment And Development}

It is a fact that source rocks are confirmed to be present and mature, for this prospect, and 20 wells penetrate AEB formation in the Qasr field. The previous work was targeting estimation of the remaining oil reserves in this moderate size field, although oil reserves are of secondary importance, they are valuable and commercial. The parameters needed for assessment and risk analysis, which will affect field development, includes the percent trap fill which is the volume of hydrocarbons inside the structural closure or in the stratigraphic reservoir. The trap area is added as the area inside oil water contact on map. Gross rock thickness of a reservoir, was used as the average net pay between minimum and maximum values in order to minimize error. Net to gross ratio of a reservoir thickness, porosity and water saturation have been selected based on Petrophysical analysis results. Net to gross ratio of a reservoir thickness ranges between 0.8 and 0.9 .

Porosity values range between 12 and $15 \%$, Water saturation is between 17 and $42 \%$, and a normal distribution probability curve was selected to give better results. The Chance of success maps (Figures.13\&14) were selected to represent the reservoir distribution uncertainty. Formation volume factor for high shrinkage oil equals 1.4 and 1.2 for low shrinkage oil, while it is selected as 1.1 minimum and 1.3 maximum values for Qasr field. Recovery factor is obtained from oil field production observations and ranges between 0.3 and 0.5 . The distribution of some of these parameters is listed in Figure.15. The correlation of uncertainty of different factors is shown in Figure.16. The chance of success is the product of multiplying the probability of the previously discussed factors. It usually ranges between 0.0 and 1.0.

Risk elements include; Source presence $=1$, Source Maturity $=1$, Reservoir quality $=0.65$, Trap quality $=0.9$, Migration $=1$. The chance of success $(C O S)=0.65$.

Estimated Reserves $=$ Reservoir Potential $\times \mathbf{C O S}=61.024 \times 0.55=33.55$ MMSTB $($ oil in place)

$$
=24.420 \times 0.55=13.42 \mathrm{MMSTB}(\text { recoverable oil })
$$


Reservoir Petrophysical Modeling and Risk Analysis in Reserve Estimation; A Case Study from ..

The Volumetric Analysis for Alam El Bueib reservoirs is shown in Figure.17with up to $70 \%$ chance of success. The volumetric analysis for AEB-3D (D2 \& D4) unit showed oil in place= 17 MMSTB with 7 MMSTB as recoverable oil. This indicates that AEB-3D is the primary reservoir with up to $50 \%$ of recoverable reserves.

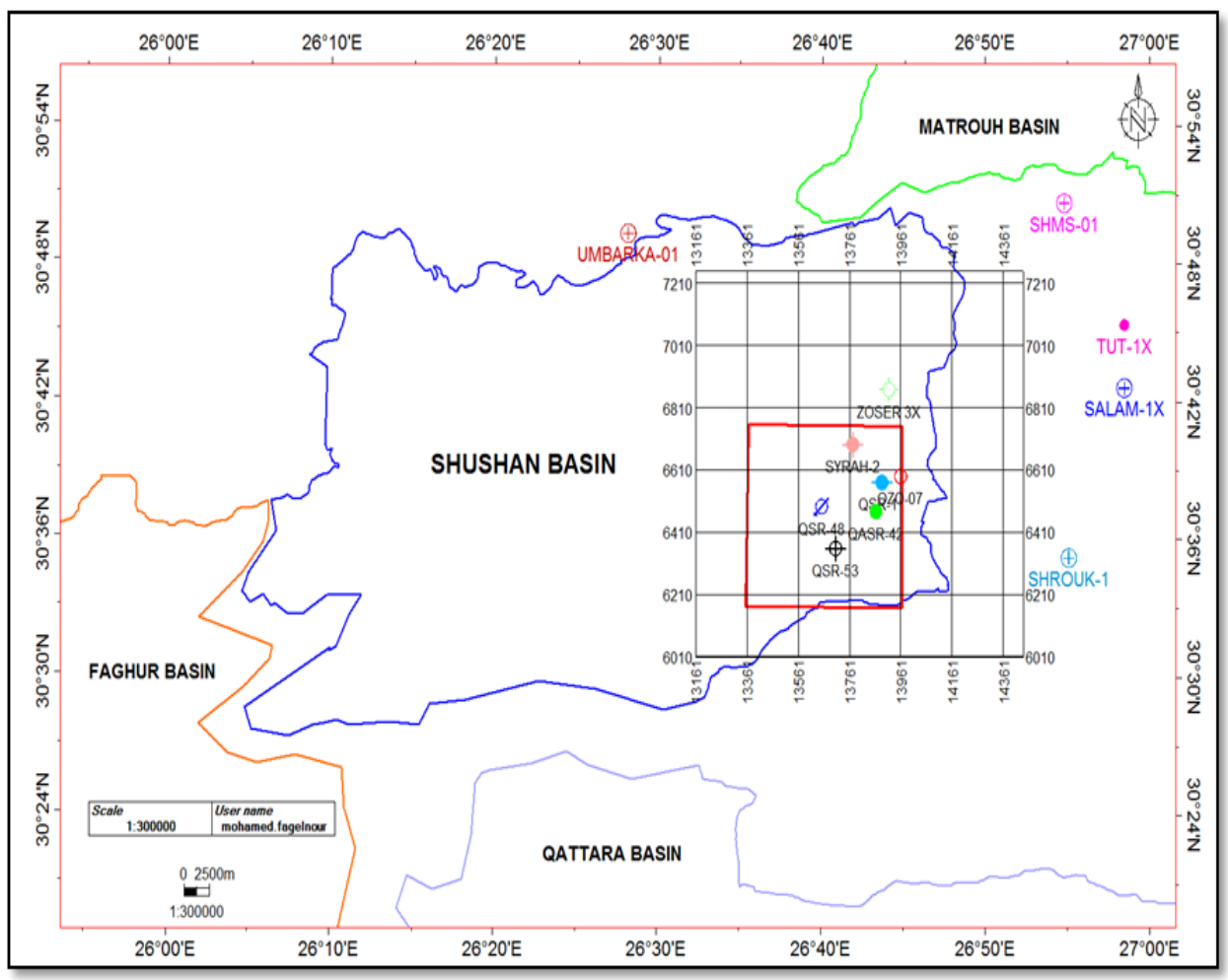

Figure.1: A map showing the location of Qasr field.

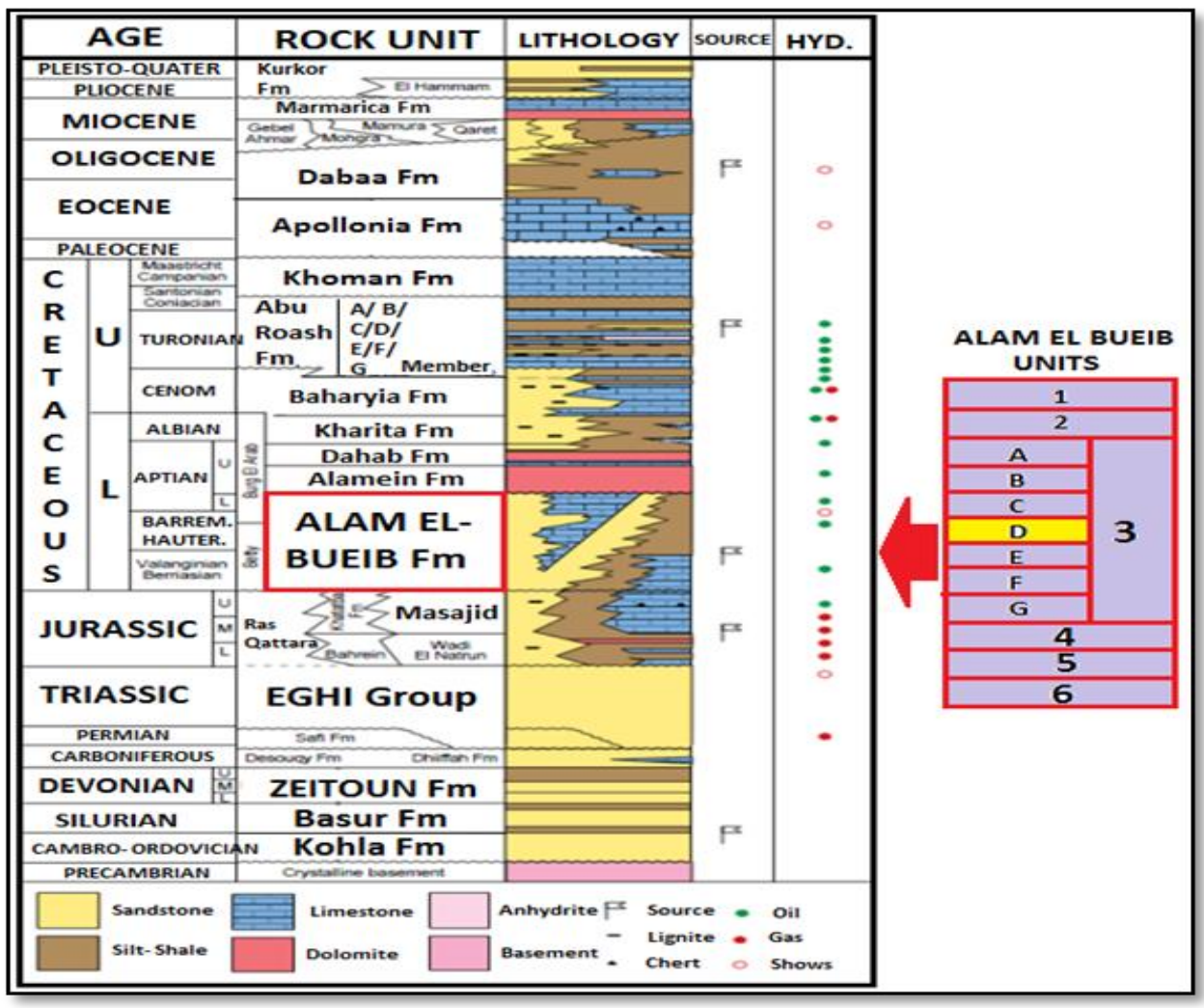

Figure.2: Stratigraphy of the study area. 


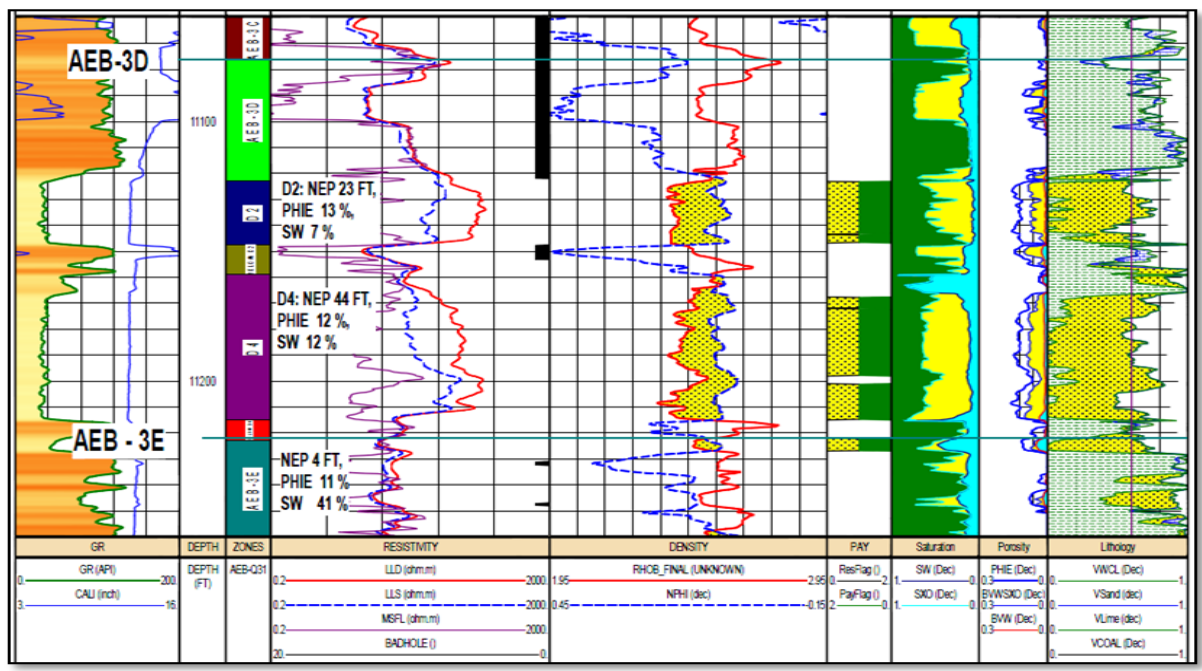

Figure.3: Litho- saturation plot of well Qasr-31.

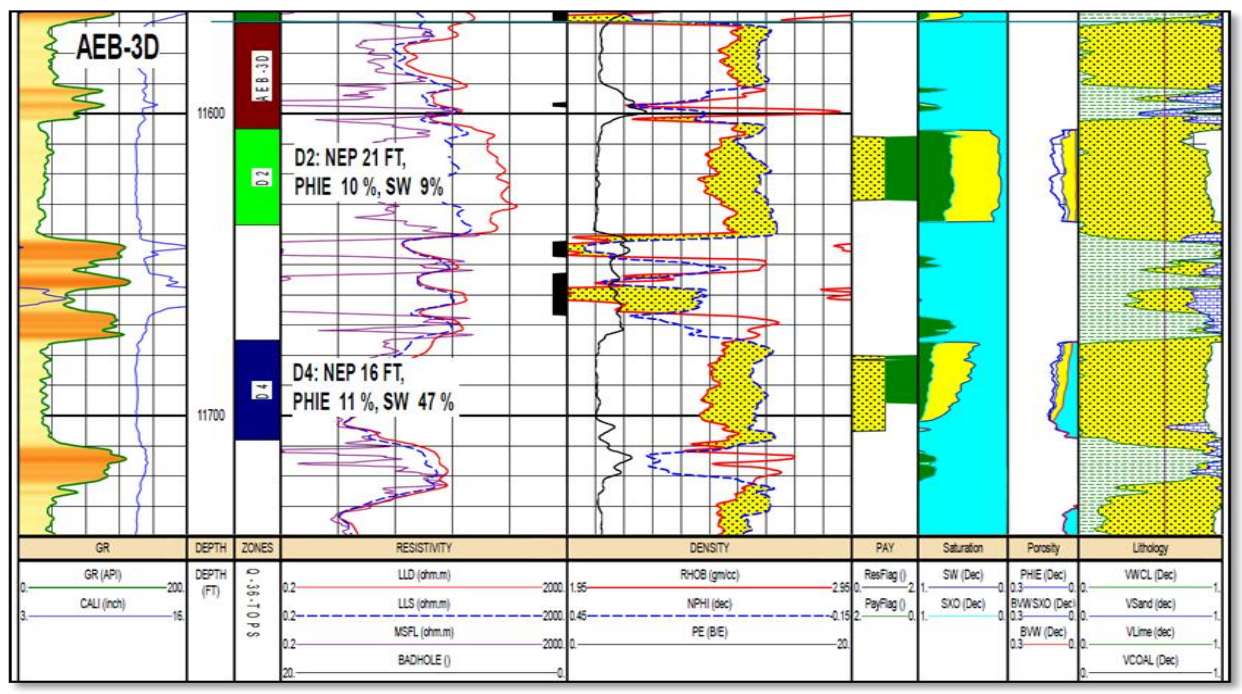

Figure.4: Litho- saturation plot of well Qasr-36.

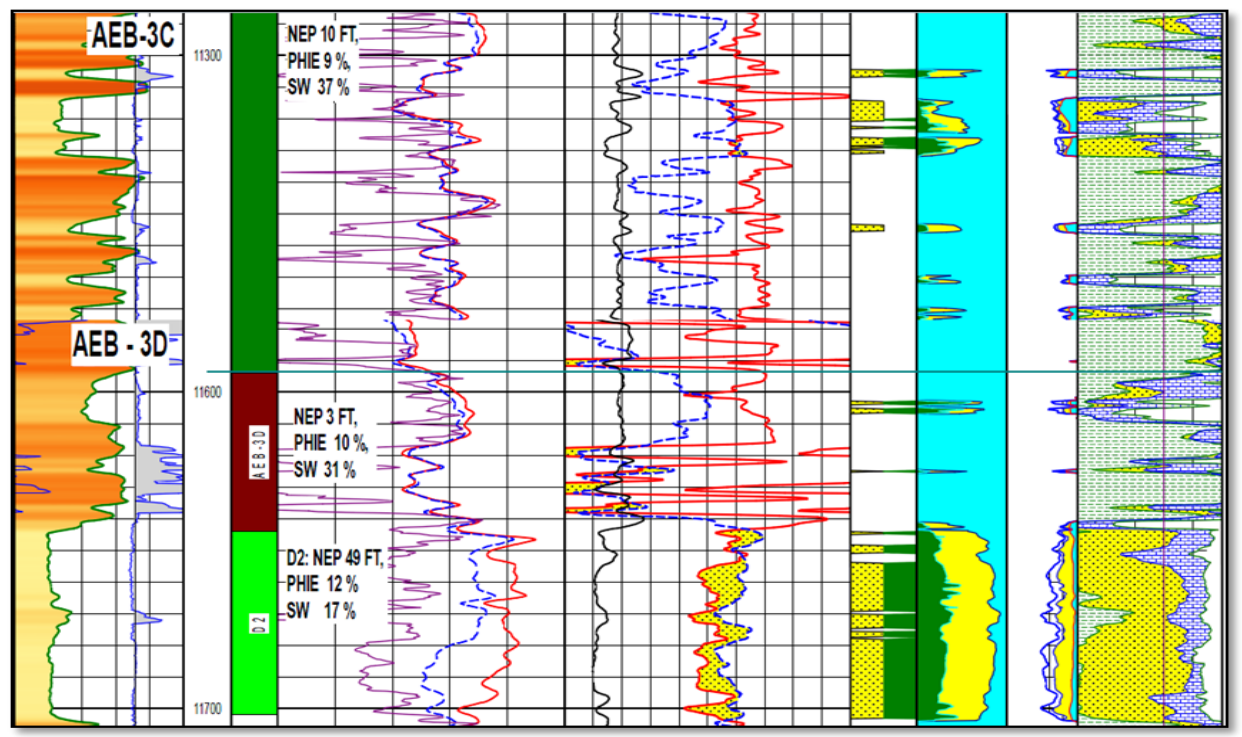

Figure.5: Litho- saturation plot of well Qasr-41. 


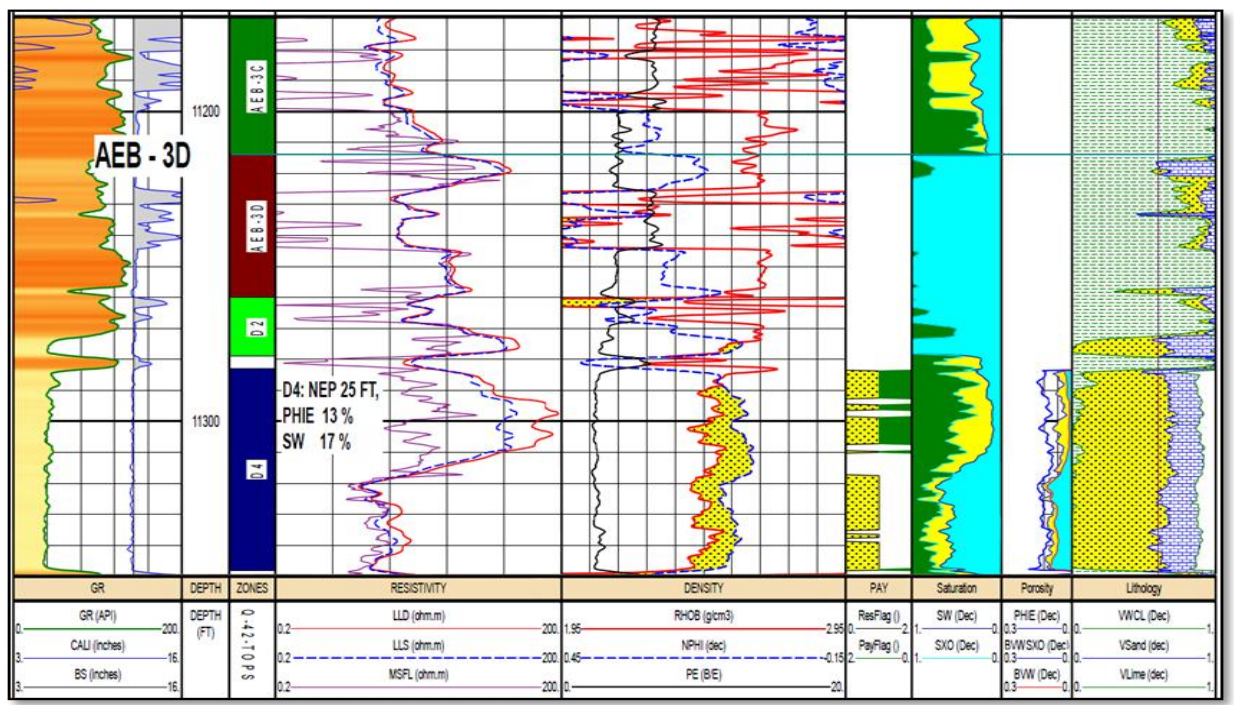

Figure.6: Litho- saturation plot of well Qasr-42.

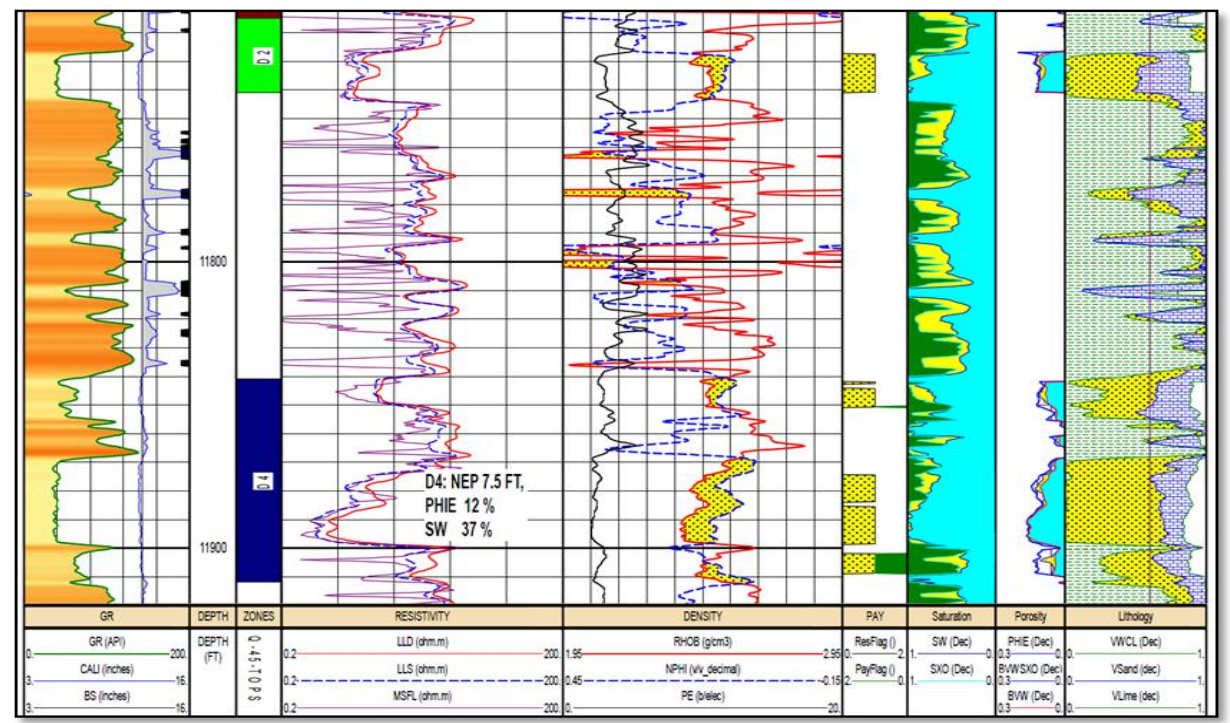

Figure.7: Litho- saturation plot of well Qasr-45.

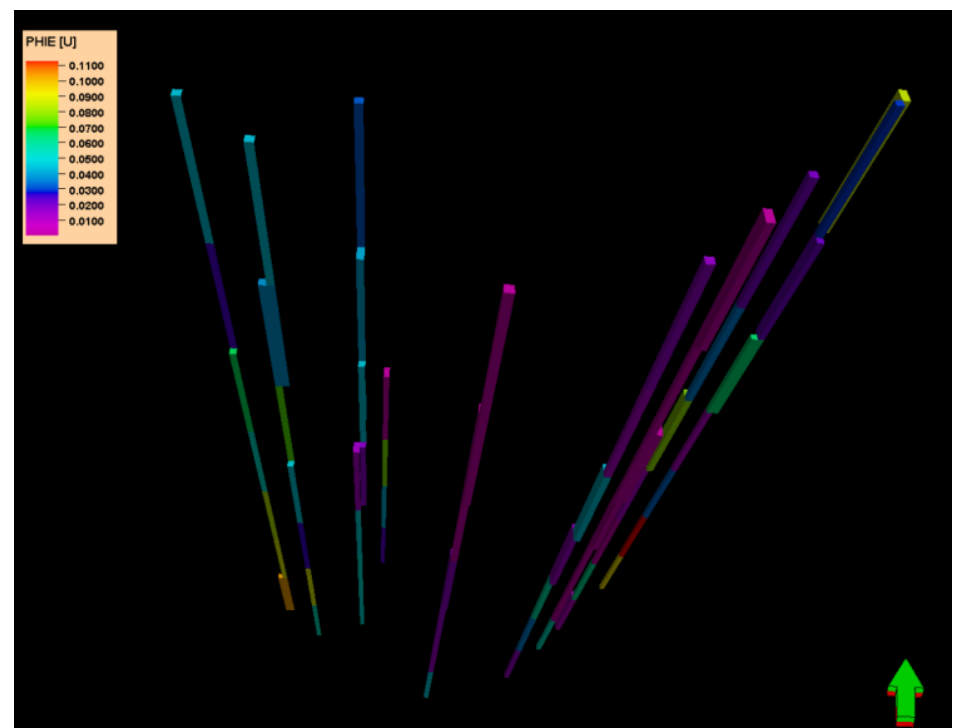

Figure.8: Up-scaled porosity logs in 10 wells from Qasr field. 


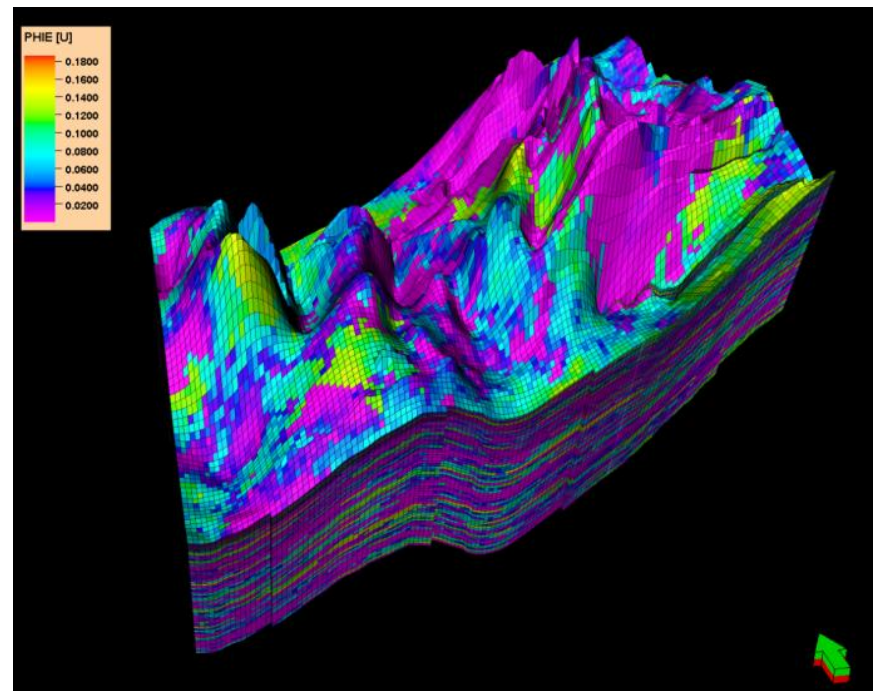

Figure.9: PHIE Petrophysical model for AEB-3D and AEB-3E zones.

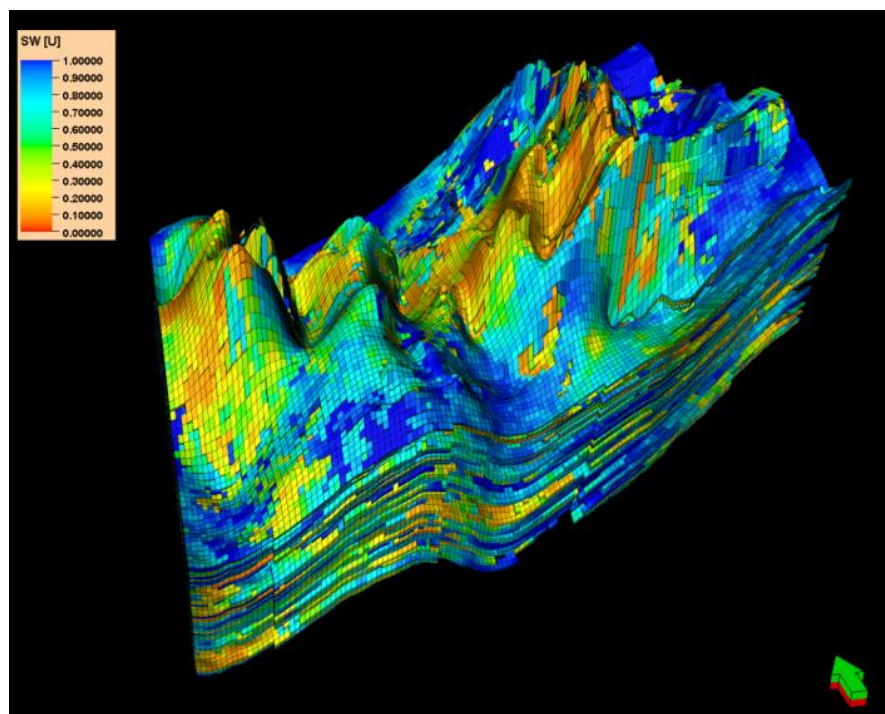

Figure.10: SW Petrophysical model for AEB-3D and AEB-3E zones.

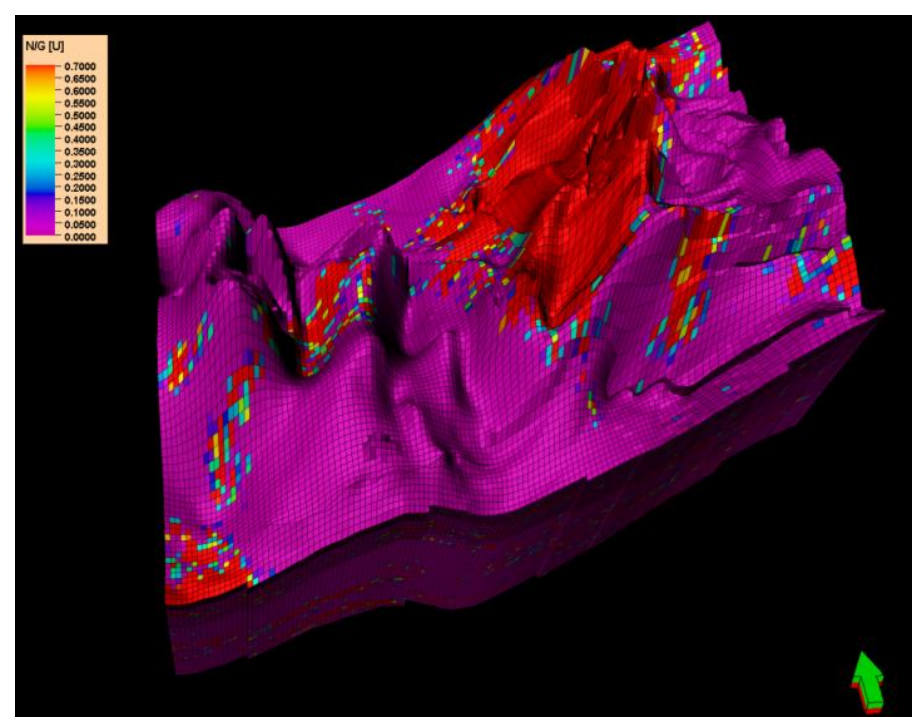

Figure.11: Net to Gross Petrophysical model for AEB-3D and AEB-3E zones. 


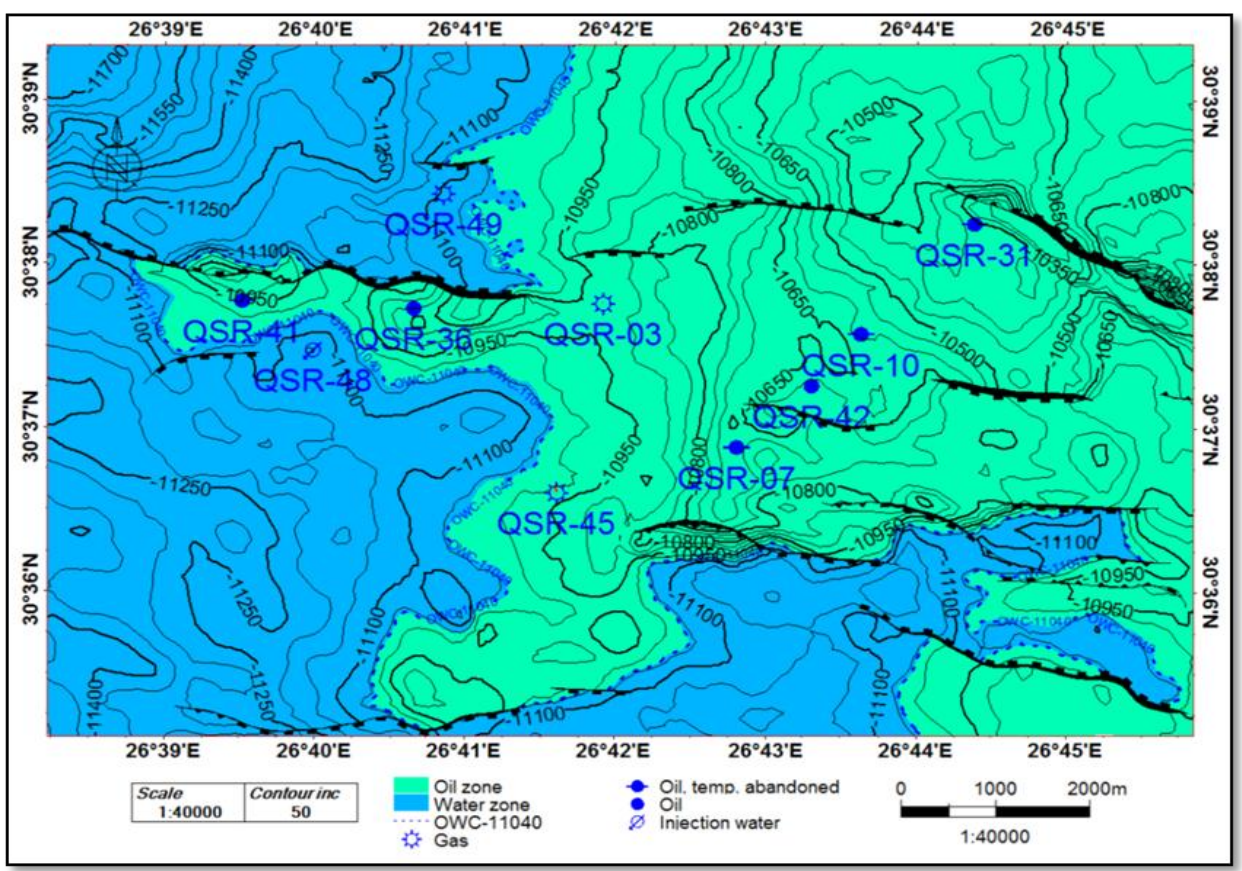

Figure.12: AEB-D2 depth structure map showing area inside oil water contact.

\begin{tabular}{|c|c|c|c|c|c|c|}
\hline Zones & $\begin{array}{c}\text { Bulk volume } \\
{\left[{ }^{*} 10^{\wedge} 6 \text { acre.ft }\right]}\end{array}$ & $\begin{array}{c}\text { Net volume } \\
{\left[{ }^{\star} 10^{\wedge} 3 \text { acre.ft }\right]}\end{array}$ & $\begin{array}{c}\text { Pore volume } \\
{\left[{ }^{\star} 10^{\wedge} 6 \mathrm{RB}\right]}\end{array}$ & $\begin{array}{c}\text { HCPV oil } \\
{\left[{ }^{*} 10^{\wedge} 6 \mathrm{RB}\right]}\end{array}$ & $\begin{array}{c}\text { STOIIP (in oil) } \\
{\left[{ }^{\star} 10^{\wedge} 6 \text { STB }\right]}\end{array}$ & $\begin{array}{c}\text { Recoverable oil } \\
{\left[{ }^{\star} 10^{\wedge} 6 \mathrm{STB}\right]}\end{array}$ \\
\hline AEB-1 & 291880.378 & 6165.953 & 5.4097 & 7.341 & 5.647 & 2.259 \\
\hline AEB-2 & 357601.354 & 7931.816 & 47.484 & 3.992 & 3.071 & 1.228 \\
\hline AEB-3A & 642963.446 & 16190.661 & 205.504 & 35.205 & 27.081 & 10.832 \\
\hline AEB-3C & 636401.379 & 15590.489 & 73.246 & 9.321 & 7.170 & 2.868 \\
\hline AEB-3D & 29211.214 & 1080.778 & 5.048 & 1.125 & 0.865 & 0.346 \\
\hline AEB-D2 & 37830.970 & 3675.323 & 44.609 & 19.991 & 15.378 & 6.151 \\
\hline AEB-D4 & 38370.882 & 865.663 & 8.538 & 2.358 & 1.814 & 0.725 \\
\hline TOTAL & 2034259.623 & 51500.682 & 438.526 & 79.331 & 61.024 & 24.410 \\
\hline
\end{tabular}

Table.1.Estimated oil reserves for AEB reservoirs.

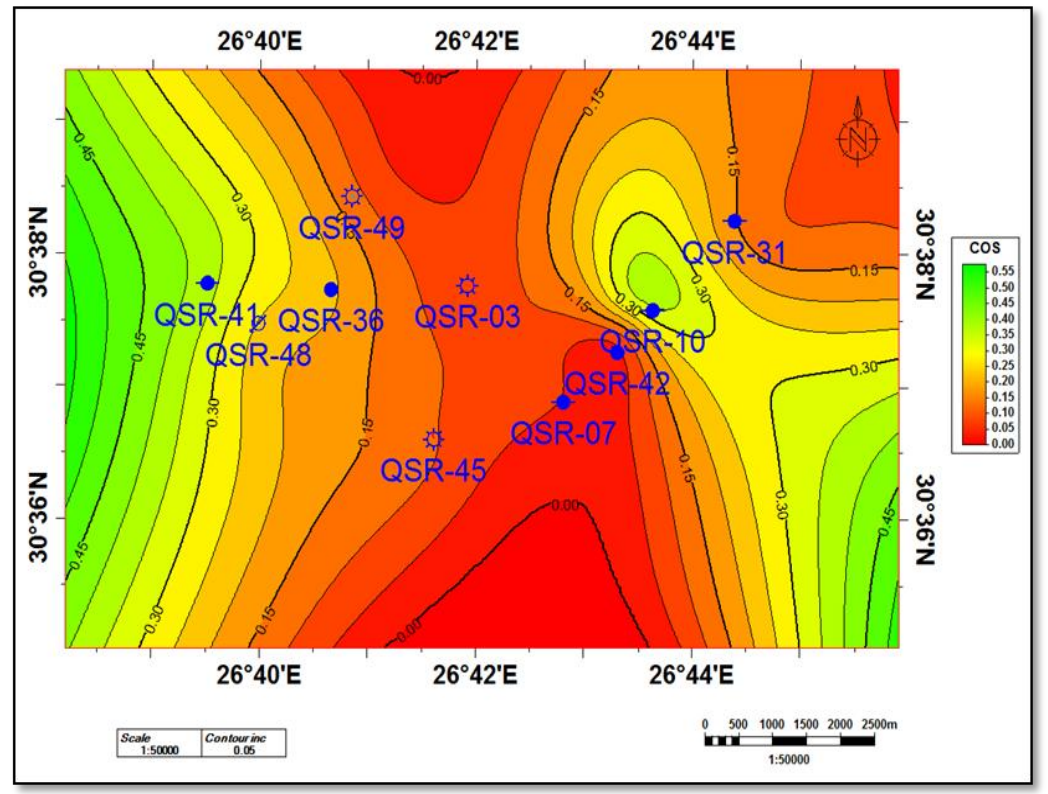

Figure.13: AEB-3D (D2) chance of success map (COS). 


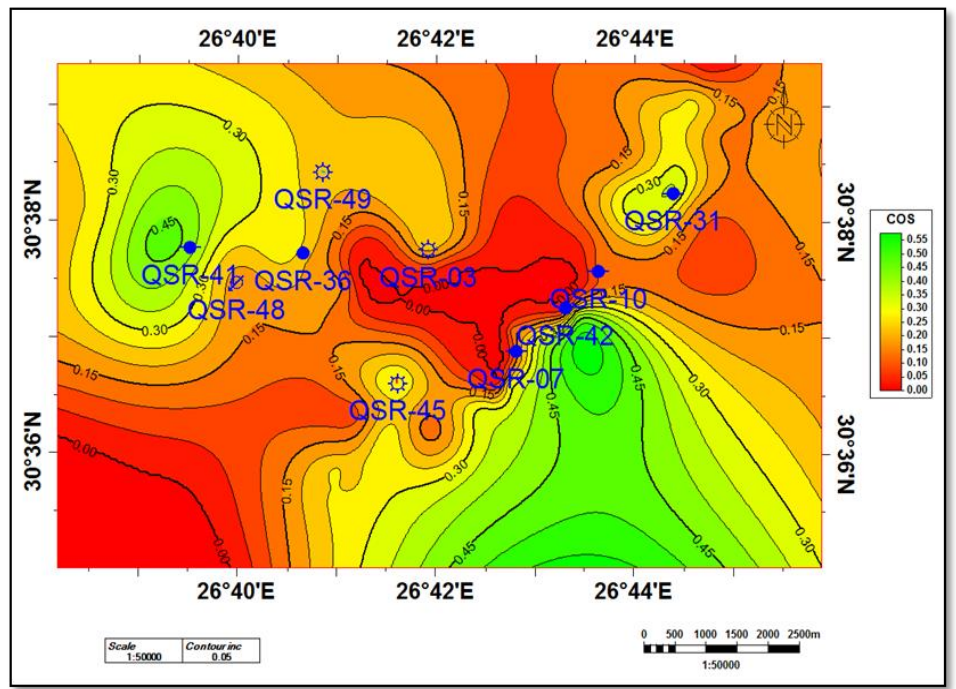

Figure.14: AEB-3D (D4) chance of success map (COS).
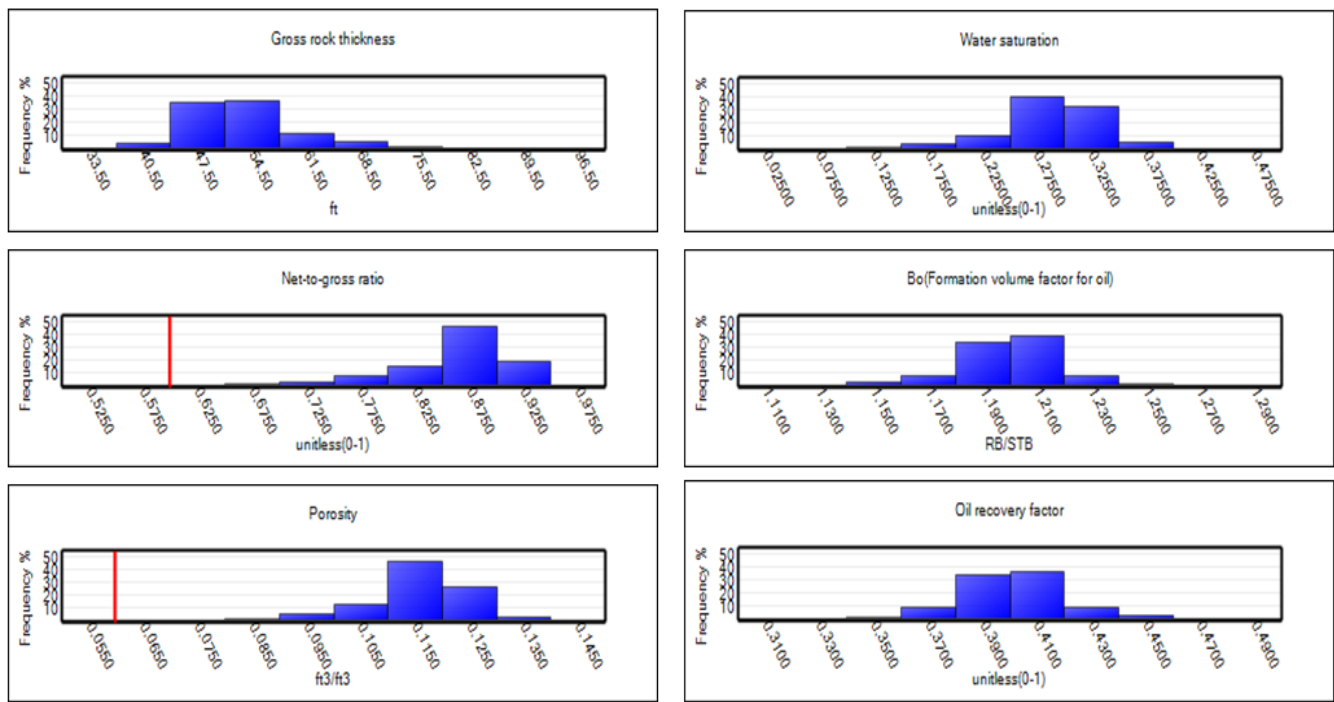

Figure.15: Distribution of parameter values used in Uncertainty analysis.

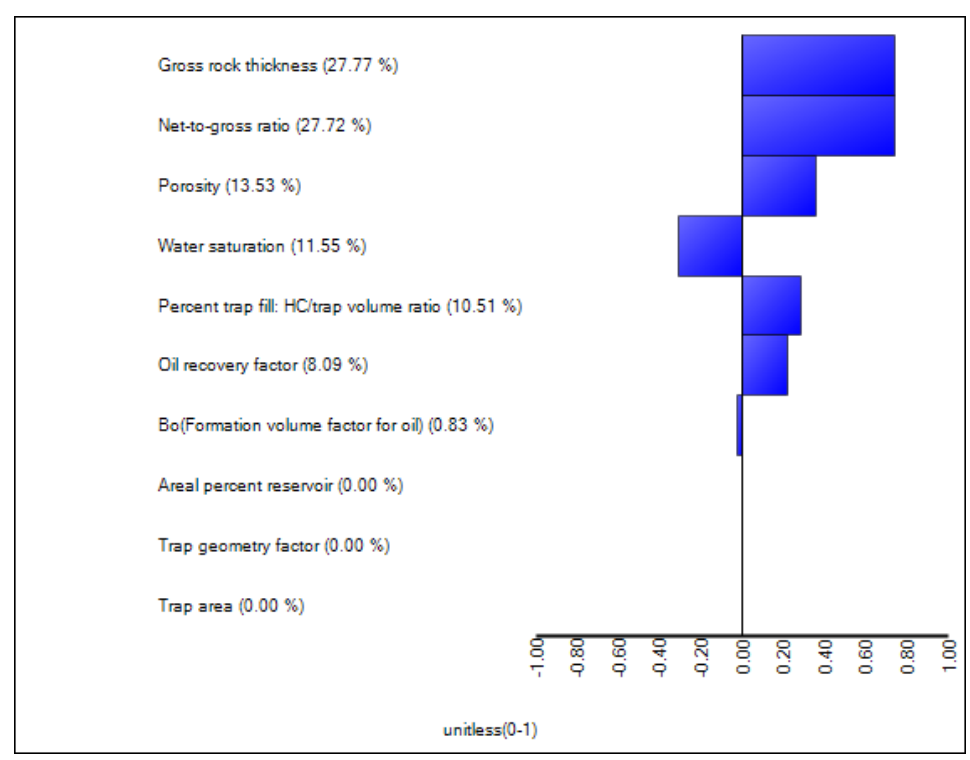

Figure.16: Uncertainty Correlation for Alam El Bueib Formation. 


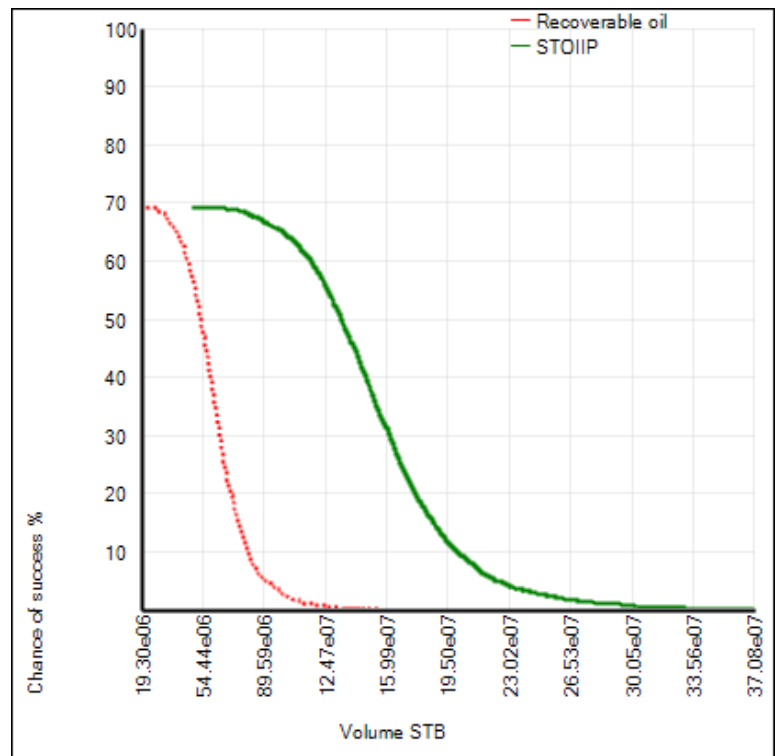

Figure.17: Volumetric Analysis for Alam El Bueib reservoirs.

\section{Conclusions}

This work shows the integration between petrophysical analysis, modeling, volumetric calculation and risk analysis, in order to make accurate reserve estimation. In addition, it is targeting the remaining oil reserves in Qasr field; although oil reserves are of secondary importance, they are valuable and commercial. Petrophysical analysis results showed that porosity of sandstone reservoirs of Alam El Bueib Formation averages $14-16 \%$ and the lower units (AEB-3D, AEB-3E) shows better porosity values. Water saturation values range from $7 \%$ to $47 \%$ in the sandstone reservoirs of all zones. Most sandstone reservoirs having net to gross values up to 0.9 , especially for the lower AEB-3D, D2 and D4 units. Petrophysical parameters of the reservoir are distributed spatially in the 3D grid. This is important for accurate estimation of hydrocarbon reserve, and determination of an oil field economics. The importance of modeling, in line with high processing computer and advanced software, is to calculate reserves most accurately and rapidly. Results confirmed that Alam El Bueib sandstone reservoirs having good petrophysical properties and their stochastic distribution are confirmed by a number of producing wells. The estimated reserve and its chance of success stated that oil producing reservoirs are satisfactory.

\section{Acknowledgement}

The authors wish to express their gratitude to the Egyptian General Petroleum Corporation (EGPC) and Khalda Petroleum Company for their permission to publish these data.

\section{References}

[1]. Schiozer D. J., Ligero E. L., Santos J. A. M., 2004.Risk Assessment for Reservoir Development Under Uncertainty, J. of the Braz. Soc. of Mech. Sci. \& Eng.

[2]. Adeoti L., Onyekachi N., Olatinsu O., Fatoba J., M. Bello 2014.Static Reservoir Modeling Using Well Log and 3-D Seismic Data in a KN Field, Offshore Niger Delta, Nigeria, International Journal of Geosciences, Volume 5, 93-106.

[3]. Archie GE., 1942. The Electrical Resistivity as an Aid in Determining Some Reservoir Characteristics. J. Petrol. Technol., 5:54-62

[4]. Schlumberger, 1972.Log interpretations. Schlumberger Inc., New York. 2: $112-116$.

[5]. Asquith G., and Krygowski D., 2004. "Basic Well Log Analysis". American Association of Petroleum Geologist Tulsa, Oklahoma, 244.

[6]. Weber KJ, 1987. Hydrocarbon Distribution Pattern in Nigeria growth fault structures controlled by structural style and stratigraphy. J. Petrol. Sci. Engine. Elsevier Science Publishers B.V. Amsterdam, 1- 12.

[7]. Holman, W.E., and Robertson, S.S., 1994. Field Development, Depositional Model, and Production Performance of the Turbiditic "J" Sands at Prospect Bullwinkle, Green Canyon 65 Field, Outer-Shelf Gulf of Mexico, GCSSEPM Foundation 15th AnnualResearch Conference, Submarine Fans and Turbidite Systems, December 4-7, p. 139-150.

[8]. Mahaffie, M.J., 1994.Reservoir classification for turbidite intervals at the Mars discovery, Mississippi Canyon 807, Gulf of Mexico.GCSSEPM Foundation 15th AnnualResearch Conference, Submarine Fans and Turbidite Systems, December 4-7, p. 233244.

[9]. McGee, D.T., Bilinski, P.B., Gary, P.S., Pfeiffer, D.S., and Sheiman.J.L., 1994. Geologic models and reservoir geometries of Auger field, deepwater Gulf of Mexico, GCSSEPM Foundation 15th Annual Research Conference, Submarine Fans and Turbidite Systems, December 4-7, p. 245-256.

[10]. Hoover, A.R., 1997. Reservoir and production characteristics of the K40 sand, South Timbalier 295, offshore Louisiana with outcrop analogues and comparison to 4D seismic results: Master thesis, The Pennsylvania State University.

[11]. Meshref, W. M., 1982. Regional structural setting of Northern Egypt.EGPC 6th Expl. Sem., Cairo, 11p.

[12]. Moussa, S., 1986.Evaluation of the sedimentary basins of the Northern Western Desert, Egypt.EGPC 8th Expl. Sem. Cairo, 14 p. 
Reservoir Petrophysical Modeling and Risk Analysis in Reserve Estimation; A Case Study from ..

[13]. Metwalli, H., Saad, M. and Ali, T. 2000.Effect of depositional environments on reservoir capacity of Upper Bahariya Formation, Meleiha Oilfields, North Western Desert, Egypt.Journal of the Sedimentological Society of Egypt, V. 8a.

[14]. Younes, M. A., Bek, M., 2003.Alamein basin hydrocarbon potentials, Northern Western Desert, Egypt. In: AAPG Annual Convention. Salt Lake City, Extended abstract, 90013, AAPG, Tulsa.

[15]. Khalifa M.A., H.A. Wanas, H.M., El-Shayeb and M.A. El-Alfy, 2005.Sequence Stratigraphy and reservoir quality of the middle Jurassic Khatatba Format ion, North Western Desert, Egypt . 1st International Conference of the Tethys, $54 \mathrm{p}$ (abstract).

[16]. Metwalli, F. I., Pigott, J. D., 2005. Analysis of petroleum system criticals of the MatruheShushan Basin, Western Desert, Egypt. Pet. Geosci. 11, 157-178.

[17]. Said R., 1962. "The Geology of Egypt", Elsevier Publishing Company, Amsterdam.

[18]. Well Evaluation Conference (WEC), Schlumberger (SLB), Egypt, 1984.

[19]. Well Evaluation Conference (WEC), Schlumberger (SLB), Egypt, 1995.

[20]. Schlumberger 1989.Principle and application of log interpretation. Schlumberger Education services, Houston.

[21]. Rider. M. H., 2002.“The Geological Interpretation of Well Logs" $2^{\text {nd }}$ edition, Whittles Publishing.

[22]. Poupon A, Leveaux J, 1971. Evaluation of Water Saturations in Shaly Formations, SPWLA 12th Annual Logging Symposium, paper O.

[23]. Schlumberger Information Solutions; 2009."Property Modeling” course.Schlumberger Publication, p.96-296.

[24]. Selley, R.C. ,1998,. Elements of Petroleum Geology.Department of Geology, Imperial College, London. pp. 83-89.

[25]. Dahlberg, E.C.,1979,. Hydrocarbon reserve estimation from contour maps.Bull. Can. Pet. Geol. 27, 94-99.

[26]. Samimi A. K., Karimi. G.,2014. Sensitivity \& Uncertainty Analysis of Original Oil-in-Place in Carbonate Reservoir Modeling, A Case study.Petroleum\& coal 56(3) 332-338.

[27]. Schlumberger Information Solutions; 2013."Exploration Geology" course. Schlumberger Publication, p. 13-15. 